\title{
Pancreatic A and B Cell Hyperfunction in the Mendenhall Syndrome
}

\author{
M. Serrano Ríos ${ }^{1}$, S. de la Viña ${ }^{1}$, M. E. Carbó ${ }^{1}$, R. E. Nash ${ }^{1}$, R. Barrio ${ }^{2}$ and L. G. Heding ${ }^{3}$ \\ ${ }^{1}$ Department of Internal Medicine and ${ }^{2}$ Department of Paediatrics, Centro Especial Ramón y Cajal, Madrid, Spain, and \\ ${ }^{3}$ Novo Research Institute, Novo Allé, Baegsvaerd, Denmark
}

\begin{abstract}
Summary. A 16-year-old boy with persistent hyperglycaemia (approximately $16 \mathrm{mmol} / \mathrm{l}$ in the fasting state) and acanthosis nigricans had insulin resistance and received daily up to $2800 \mathrm{U}$ of short-acting, soluble, highly purified porcine insulin. The number and affinity of insulin receptors were markedly decreased. No significant insulin binding to IgG could be detected. Immunoreactive insulin varied between 1344 and $2400 \mathrm{mU} / \mathrm{l}$. Endogenous insulin secretion and proinsulin levels were grossly elevated in the fasting state (C-peptide $2.2-3.5 \mathrm{pmol} / \mathrm{ml}$; proinsulin approximately $1 \mathrm{pmol} / \mathrm{ml}$ ). After an oral glucose tolerance test and intravenous arginine infusion, B cell hypersecretion was confirmed. The molar ratio of C-peptide to immunoreactive insulin, normally approximately 7 , was about 0.3 , clearly indicating that most of the im-
\end{abstract}

munoreactive insulin was exogenous. The molar ratio of proinsulin to C-peptide, which is about 0.05 in fasting control subjects, was $0.23-0.45$, clearly showing that too high a proportion of proinsulin was being secreted. This may indicate that the constant hyperstimulation of the B cell leads to reduced conversion of proinsulin to insulin. Immunoreactive glucagon levels were within normal limits fasting but were above normal after intravenous arginine infusion. Thus, in this case of diabetes with acanthosis nigricans, the severe insulin resistance, probably caused by a receptor defect, was associated with markedly increased $B$ cell function.

Key words: Acanthosis nigricans, insulin resistance, C-peptide, proinsulin, diabetes mellitus, glucagon.
Recent research using receptor assays has shown that insulin-resistant states associated with the so-called acanthosis nigricans syndromes are mostly due to defects at the receptor level or are post-receptor binding defects $[14,15]$. In a patient suffering from a peculiar variant of acanthosis nigricans syndrome and severe insulin-resistant diabetes (Mendenhall syndrome) $[4,6$, $16,24,25$, we described the virtual disappearance of insulin receptor in erythrocytes [18]. The reaction of the endocrine pancreas to prolonged and extreme endogenous insulin resistance is unknown and therefore the present study was undertaken to investigate $A$ and $B$ cell responses to oral glucose and intravenous arginine infusion in this patient.

\section{Material and Methods}

\section{Patient}

The patient was a 16-year-old Caucasoid boy, born to a non-consanguineous marriage after a normal pregnancy. Delivery was complicated by respiratory distress requiring prompt resuscitation. Examination at birth showed striking phenotypic features: abdominal disten- sion, acromegaloid facial features, macroglossia, acanthosis nigricans around the neck and in flexure areas, as well as anal and lingual papillomata. Psychomotor development from the perinatal period up to the age of 16 years was estimated to be only moderately retarded. At the age of 3 years, peptic ulcer-like symptoms lead to a radiological and endoscopic diagnosis of diffuse gastric papillomata; the symptoms subsided with antacid therapy. At the age of 5 years macrogenitosomy was prominent and a testicular biopsy revealed an advanced degree of maturity for his age, but no hormonal studies at that time are available. Growth was estimated to be in the 25 th percentile (Stuart chart) at the age of 7 years, reaching the third percentile when the patient was aged 16 years. Occasional bouts of sudden unconsciousness without seizures were recorded at the age of 3 years, and an increased focal electric activity of the right hemisphere was established in the electroencephalogram. However, an air-encephalogram performed when the patient was 4 years old, and computerized axial tomography of the skull carried out at age 16 years, failed to detect any significant intracranial abnormality other than pineal calcification. Retarded dentition with tooth dysplasia was a prominent additional feature observed at the age of 5 years.

Marked polydipsia, polyphagia and polyuria lead to the diagnosis of diabetes mellitus at the age of 11 years. Insulin therapy was started using four to five injections a day of short-acting monocomponent porcine preparations, but within a few months increased doses of up to 2500-2800 U daily were required. Despite these high doses, hyperglycaemia ( $>11 \mathrm{mmol} / \mathrm{l})$ without ketonuria persists up to the present. Careful assessment of endocrine function was carried out when the patient was 12 years old. FSH, $\mathbf{L H}$, testosterone, TSH and prolactin 


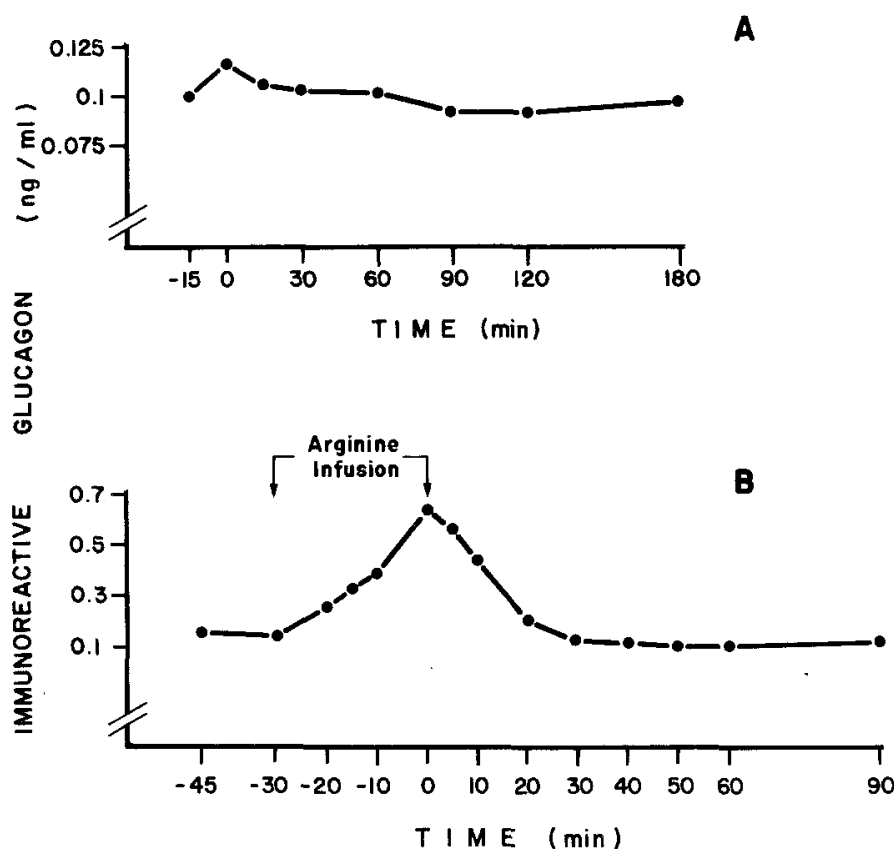

Fig. 1. Immunoreactive glucagon during (A) an oral glucose tolerance test $(1.75 \mathrm{~g} / \mathrm{kg}$ body weight), and $(\mathrm{B})$ arginine infusion $(500 \mathrm{mg} / \mathrm{kg}$ body weight) in the patient

Table 1. Serum glucose, immunoreactive insulin, C-peptide and proinsulin levels in the patient

\begin{tabular}{|c|c|c|c|c|}
\hline $\begin{array}{l}\text { Time } \\
(\min )\end{array}$ & $\begin{array}{l}\text { Glucose } \\
(\mathrm{mmol} / \mathrm{l})\end{array}$ & $\begin{array}{l}\text { IRI } \\
(\mathrm{mU} / 1)\end{array}$ & $\begin{array}{l}\text { C-peptide } \\
(\mathrm{pmol} / \mathrm{ml})\end{array}$ & $\begin{array}{l}\text { Proinsulin } \\
(\mathrm{pmol} / \mathrm{ml})\end{array}$ \\
\hline \multicolumn{5}{|c|}{ After oral glucose tolerance test $(1.75 \mathrm{~g} / \mathrm{kg}$ body weight) } \\
\hline-15 & 16.6 & 1344 & 2.25 & 1.00 \\
\hline 0 & 16.1 & 1344 & 1.75 & 0.80 \\
\hline 15 & 24.0 & 2240 & 5.00 & 1.20 \\
\hline 30 & 28.2 & 2304 & 4.50 & 1.30 \\
\hline 60 & 34.4 & 2272 & 5.00 & 1.50 \\
\hline 90 & 29.8 & 2176 & 3.75 & 1.30 \\
\hline 120 & 25.6 & 2016 & 3.25 & 0.90 \\
\hline 180 & 19.2 & 1728 & 1.75 & 0.90 \\
\hline \multicolumn{5}{|c|}{ After arginine infusion $(500 \mathrm{mg} / \mathrm{kg}$ body weight, $-30-0 \mathrm{~min})$} \\
\hline-45 & 17.6 & 1696 & 3.50 & 0.80 \\
\hline-30 & 17.8 & 1600 & 3.00 & 0.60 \\
\hline-20 & 17.8 & 2112 & 5.25 & 1.00 \\
\hline-15 & 18.0 & 2112 & 4.50 & 1.30 \\
\hline-10 & 17.9 & 1856 & 3.75 & 1.00 \\
\hline 0 & 19.3 & 2400 & 5.00 & 1.10 \\
\hline 5 & 19.6 & 2272 & 4.25 & 1.00 \\
\hline 10 & 19.8 & 2048 & 3.50 & 1.50 \\
\hline 20 & 19.5 & 1728 & 2.75 & 0.70 \\
\hline 30 & 18.7 & 1632 & 2.75 & 0.70 \\
\hline 40 & 17.9 & 1536 & 2.50 & 0.80 \\
\hline 50 & 16.9 & 1444 & 2.25 & 0.70 \\
\hline 60 & 16.0 & 1344 & 2.25 & 0.40 \\
\hline 90 & 15.6 & 1408 & 2.50 & 0.60 \\
\hline
\end{tabular}

responses to TRH and LHRH were normal. Evaluation of thyroid and adrenal function was reported as normal, as well as basal and arginine-stimulated growth hormone release.

At the time of our study (September 1981), acanthosis nigricans, lingual papillomatosis and insulin-resistant diabetes mellitus were prominent features. There was no evidence of retinopathy by conventional funduscopy or fluorescein angiography, nor could peripheral neuropathy be detected. Renal function was within normal limits. Conventional haematological and blood chemistry studies showed no significant abnormalities apart from hyperglycaemia and mild hypertriglyceridaemia. Family history revealed that the patient's parents and a younger brother were healthy and of normal appearance. However, an elder brother suffering from insulin-resistant diabetes and acanthosis nigricans had died aged 2 years. A first degree cousin has also been diagnosed as insulin-resistant with defective insulin receptors and acanthosis nigricans [17].

\section{Special Studies}

An oral glucose tolerance test ( $1.75 \mathrm{~g}$ glucose $/ \mathrm{kg}$ body weight) and arginine hydrochloride infusion $(500 \mathrm{mg} / \mathrm{kg}$ body weight) were carried out 7 days apart, after $12 \mathrm{~h}$ of fasting and withdrawal of insulin therapy for $24 \mathrm{~h}$. For each test, blood samples were taken at predetermined times into precooled tubes (with/without heparin-aprotinin) for either serum or plasma as appropriate. Aliquots of serum were used for immediate glucose assay (in triplicate) by the glucose oxidase method using a calibrated Beckman autoanalyzer. The appropriate aliquots (serum or plasma) were immediately frozen at $-20^{\circ} \mathrm{C}$ for radioimmunoassay of: (1) total insulin (antibody-bound immunoreactive insulin + 'free' immunoreactive insulin) (IRI) - interassay coefficient of variation 10.4\%, lower detection limit < $1 \mathrm{mU} / 1$ [9]; (2) C-peptide, determined after removal of proinsulin by Sepharose-bound insulin antibodies (S-AIS) [10] - inter-assay coefficient of variation 9.2\%, lower detection limit of $0.03 \mathrm{pmol} / \mathrm{ml}$; (3) Proinsulin, bound to S-AIS [11], determined using antiserum $\mathrm{K} 1219$ in an improved assay in which human proinsulin shows about $66 \%$ cross-reactivity with insulin in the range $0-0.50 \mathrm{pmol} / \mathrm{ml}$-inter-assay coefficient of variation $10 \%$, lower detection limit $0.002 \mathrm{pmol} / \mathrm{l}$ [12]; (4) glucagon (8) - inter-assay coefficient of variation $8.6 \%$, lower detection limit $<0.026 \mathrm{ng} / \mathrm{ml}$ in plasma samples. Intra-assay coefficients of variation were approximately $2.5 \%$ in all assays. Assays were carried out within 3 months after sampling at Dr. L. Heding's laboratory, Novo Research Institute, Copenhagen. Insulin binding IgG was determined by radioimmunoelectrophoresis according to Christiansen, non-specific binding being $40 \mathrm{mU} / 1$ [3].

Insulin binding to erythrocytes was carried out according to Gambhir et al. [7]. Insulin binding to cultured fibroblasts obtained from skin biopsy was studied by the method of Rechler and Podskalny [21]. Mono- ${ }^{125} \mathrm{I}$-(tyr A14)-insulin was the tracer in the binding studies [13], and monocomponent cristalline porcine insulin (26.9 $\mathrm{U} / \mathrm{mg}$ ) was used as standard $\left(0-10^{5} \mathrm{ng} / \mathrm{ml}\right)$ in the competition experiments. Both preparations were a gift from Novo Reserach Institute. Results of the competition studies were interpreted using the Scatchard plot method. Results are expressed as mean \pm SD for erythrocyte assays and as mean \pm SEM for fibroblast assays.

The precision of the insulin binding assays was determined on the basis of the $\mathrm{ID}_{50}$, that is the amount of unlabelled insulin required to inhibit $50 \%$ of the ${ }^{125} \mathrm{I}$-insulin binding to the receptors. For insulin binding to erythrocytes the $\mathrm{ID}_{50}$ was $4.33 \pm 1.3 \mathrm{ng} / \mathrm{ml}$ (mean $\pm \mathrm{SD}$; $\mathrm{n}=17$ ); in the case of insulin binding to fibroblasts, the $\mathrm{ID}_{50}$ was $2 \pm$ $1.37 \mathrm{ng} / \mathrm{ml}$ (mean $\pm \mathrm{SD} ; n=3$ ). The coefficients of variation (intra-assay) for our insulin binding studies were $<10 \%$.

\section{Control Subjects}

For radioimmunological determinations of total insulin, C-peptide and proinsulin, control samples consisted of serum obtained from 13 fasting normal subjects. For immunoreactive glucagon assays control samples from 26 fasting healthy volunteers were tested; with regard to control samples for insulin binding to erythrocytes, 17 normal volunteers (age 24-43 years) were studied. The control fibroblast lines were derived from three normal subjects. In none was there a family or personal history of diabetes mellitus. 


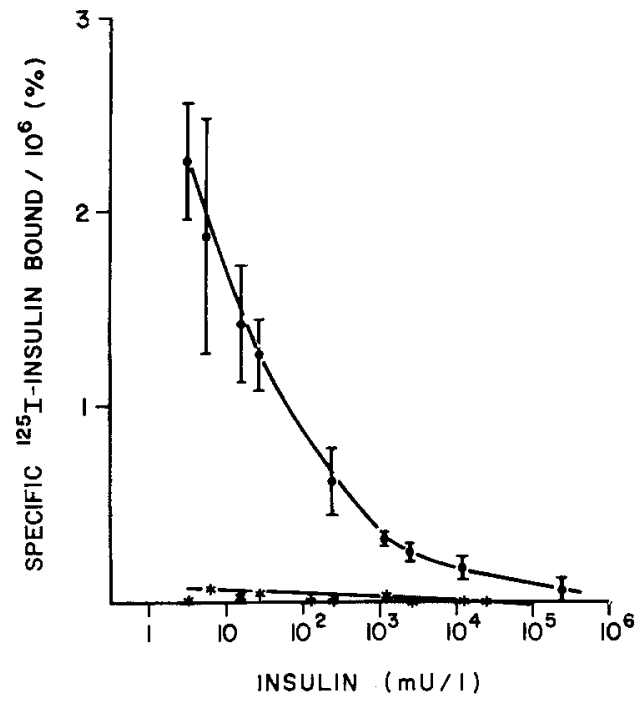

Fig. 2. ${ }^{125}$ I-insulin binding to fibroblasts. Competition-inhibition curve. Binding was determined using $1.5-3.5 \times 10^{6}$ cells $/ \mathrm{ml}$, incubated during $3 \mathrm{~h}$ at $15^{\circ} \mathrm{C}$ with $125-150 \mathrm{pg} / \mathrm{ml}$ of ${ }^{125} \mathrm{I}$-(tyr A14)-insulin and the indicated concentration of porcine insulin, in $0.5 \mathrm{ml}$ of buffer assay $(\mathrm{pH} 8)$ containing $1 \%$ of bovine serum albumin. Values expressed as mean $\pm \mathrm{SEM}$ in the control group $\longrightarrow,(n=3)$; Mendenhall syndrome *—

Table 2. Molar ratios in response to an oral glucose tolerance test

\begin{tabular}{rll}
\hline Time (min) & $\begin{array}{l}\text { C-peptide: IRI } \\
\text { (pmol/pmol) }\end{array}$ & $\begin{array}{l}\text { Proinsulin:C-Peptide } \\
(\text { pmol/pmol) }\end{array}$ \\
\hline-15 & 0.27 & 0.44 \\
0 & 0.21 & 0.45 \\
15 & 0.45 & 0.24 \\
30 & 0.31 & 0.29 \\
60 & 0.36 & 0.30 \\
90 & 0.27 & 0.35 \\
120 & 0.26 & 0.27 \\
180 & 0.16 & 0.51 \\
\hline
\end{tabular}

\section{Results}

Insulin antibodies were detectable at low concentrations, actual values 1 year apart being 96 and $159 \mathrm{mU} / 1$. The $\mathrm{B}$ cell response to oral glucose is shown in Table 1 . Serum glucose rose from 16.6 to $34.4 \mathrm{mmol} / \mathrm{l}$. IRI varied from 1344 to $2304 \mathrm{mU} / \mathrm{l}$ and C-peptide from approximately 2 to $5 \mathrm{pmol} / \mathrm{ml}$. Fasting proinsulin was very high (approximately $1 \mathrm{pmol} / \mathrm{ml}$ ) and increased slightly during the test. Before and during the intravenous arginine test (Table 1) glucose, IRI, C-peptide and proinsulin levels fluctuated, but all four parameters showed a decrease after the infusion was discontinued.

The molar ratios between C-peptide and IRI, and between C-peptide and proinsulin after the oral glucose tolerance test are shown in Table 2. The C-peptide: IRI ratio was far higher than that observed in the normal subjects. The same was the case for the proinsulin: Cpeptide ratio. After the arginine infusion, similar ratios were found for C-peptide:IRI $(0.26-0.39)$ and for proinsulin: C-peptide (0.18-0.42).

Immunoreactive glucagon levels, fasting and after each test, are shown in Figure 1 (normal fasting values varied between 0.070 and $0.120 \mathrm{ng} / \mathrm{ml}$; mean $\pm \mathrm{SD}$ $0.091 \pm 0.013 \mathrm{ng} / \mathrm{ml}, n=26$ ). Basal levels of immunoreactive glucagon were normal, but after the oral glucose tolerance test no significant suppression of immunoreactive glucagon was observed (Fig.1A). On the other hand, arginine infusion elicited a normal timeresponse pattern with markedly elevated absolute values at all times (Fig. 1B), specially when taking the glucose values into account.

Data concerning insulin binding to erythrocytes have been partially presented [22]. Insulin binding to erythrocytes and fibroblasts is shown in Table 3 and Figure 2 respectively. ${ }^{125}$ I-insulin binding is dramatically diminished in erythrocytes (specific maximal bound $=0.99 \pm 0.41 \% ; n=4$ different assays) when compared with the control group (specific maximal bound $=12.01 \pm 1.51 \%$; mean $\pm \mathrm{SD} ; n=17$ males). In cultured fibroblasts the specific maximal bound/ $10^{6}$ cells is $0.065 \%$ in comparison with $2.27 \pm 0.21 \%$ (mean $\pm \mathrm{SEM} ; n=3$ ) in the control subjects. The calculated receptor number in erythrocytes was markedly reduced ( $32 \pm 7$ sites/cell) when compared with controls $(79 \pm 11 \mathrm{sites} /$ cell $)$, whereas receptors where virtually absent in the cultured fibroblasts. In both systems, the extremely low maximal binding, particularly in fibroblasts, made the interpretation of results using the Scatchard plot method even more complicated, it being almost impossible to derive the average affinity profile according to De Meyts and Roth [5].

\section{Discussion}

Insulin-resistant diabetic patients with acanthosis nigricans have been classified as types A, B and C according to the level of the receptor defect $[1,2,14]$. Our patient, having an acanthosis nigricans insulin-resistant state with a decreased number and affinity of the insulin receptors in two systems (erythrocytes and cultured fibroblasts) and no anti-receptor factors [22], should be considered a type A genetic variant. Furthermore, the low levels of IgG insulin antibodies make it unlikely that the resistance was caused by insulin antibodies. Further studies recently carried out by Taylor et al. [23] in this patient have also established abnormally low levels of insulin binding to cultured lymphocytes and to cultured skin fibroblasts, with a concomitant decrease in the affinity of ${ }^{125} \mathrm{I}$-insulin binding to the latter cell system. All these findings are in agreement with the observations of Podskalny and Kahn $[19,20]$ in cultured fibroblasts from patients suffering from other syndromes of extreme insulin resistance.

On the other hand, our findings established a striking over-activity of both A and B cells. We found very 
Table 3. ${ }^{125} \mathrm{I}$-insulin binding to erythrocytes in vitro

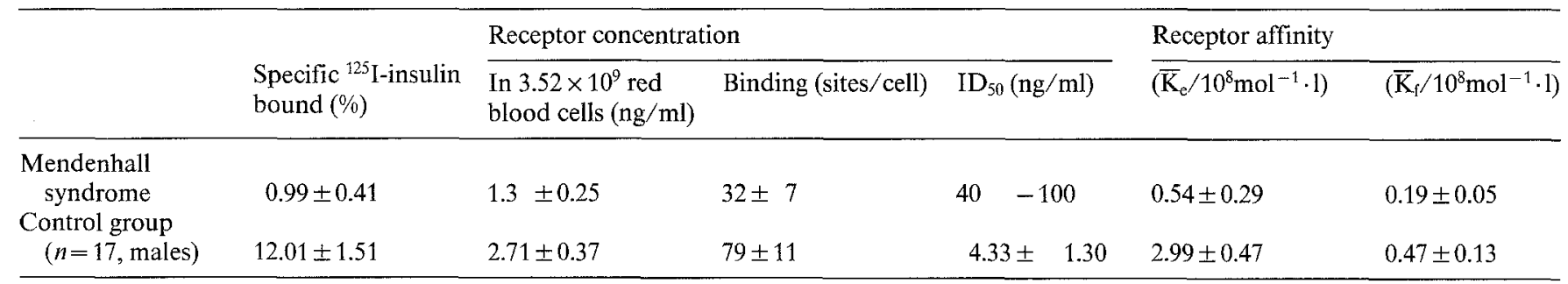

Results expressed as mean \pm SD

high levels of circulating IRI activity, consisting of a mixture of exogenous insulin (2800 U of short action monocomponent porcine insulin/day), endogenous insulin (C-peptide in the fasting but hyperglycaemic condition being $1.75-3.50 \mathrm{pmol} / \mathrm{ml}$ ) and endogenous proinsulin $(0.60-1.00 \mathrm{pmol} / \mathrm{ml})$. In fact, the molar ratio between C-peptide and IRI, which in normal fasting subjects is approximately $7: 1$, was $0.21-0.39$, clearly showing that most of the IRI was exogenous. This indicated that despite the high dose of exogenous insulin and the resulting high plasma concentration of IRI, endogenous B cell secretion was excessive and not suppressed, as shown by a fasting C-peptide concentration of $1.75-3.50 \mathrm{pmol} / \mathrm{ml}$ when plasma glucose was approximately $17 \mathrm{mmol} / 1$, which markedly increased after oral glucose. Fasting C-peptide levels in the 13 normal subjects were $0.49 \pm 0.22 \mathrm{pmol} / \mathrm{ml}($ mean $\pm \mathrm{SD})$. Basal proinsulin was increased $(0.60-1.00 \mathrm{pmol} / \mathrm{ml})$ compared with normal subjects $(0.024 \pm 0.020 \mathrm{pmol} / \mathrm{ml})$ [12]. In addition, the ratio between proinsulin and $\mathrm{C}$ peptide (normally $0.05 \pm 0.03$ [12]) was increased tenfold. This again clearly indicates that a much higher proportion of unconverted proinsulin is being secreted than in normal subjects. The molar plasma proinsulin concentration was at least fivefold higher than that of the endogenously secreted insulin. Such hyperproinsulinaemia has not been reported previously under these circumstances. In one study by Bar et al. [2] using a filtration method for the evaluation of the proinsulin, it was found that proinsulin was less than $10 \%$ of the IRI, and the authors concluded that the resistance could not be caused by an excessive concentration of proinsulin.

Interestingly enough, A cell hyperfunction was also present, as indicated by the arginine-induced hyperglucagonaemia although the normal glucose-induced fall in glucagon release was barely present in the oral glucose tolerance test. These findings lead us to conclude that the insulin resistant state of our Mendenhall syndrome patient is characterized by a certain A cell hyperfunction as well as by marked B cell responses occurring concomitantly with a lack of peripheral insulin receptors. Of paramount interest is the hyperproinsulinaemic state present, but whether this is a primary defect or a consequence of the long-standing, extremely hyperglycaemic, insulin resistant state cannot be established by the present study. Neither is it possible to draw any conclusions about the apparently autonomous hyperfunction of $A$ and $B$ cells. Further studies on this patient and his family are currently being conducted to try to elucidate whether we are dealing with a hitherto undescribed combination of two genetic defects: abnormal proinsulin to insulin conversion, and a concomitant genetically determined defect in insulin receptors in several cell systems.

Acknowledgements. We wish to thank Dr. R. Yturriaga, Servicio de Pediatría, Centro Especial Ramón y Cajal, Madrid, Spain, for referring the patient for studies. This study was supported by a grant from the "Fondo de Investigaciones Sanitarias", expediente 242/81 and was partly presented at the 16th Annual Meeting of the European Association for the Study of Diabetes, Athens, Greece, September 1980. S. de la Viña was a Research Fellow of the "Fondo de Investigaciones Sanitarias", for the period 1981-1982.

\section{References}

1. Bar RS, Muggeo M, Kahn CR, Gorden Ph, Roth J (1980) Characterization of insulin receptors in patients with the syndromes of insulin resistance and acanthosis nigricans. Diabetologia 18: 209-216

2. Bar RS, Muggeo M, Roth J, Kahn CR, Havrankova J, ImperatoMcGinley J (1978) Insulin resistance, acanthosis nigricans, and normal insulin receptors in a young woman: Evidence for a postreceptor defect. J Clin Endocrinol Metab 47: 620-625

3. Christiansen AH (1973) Radioimmunoelectrophoresis in the determination of insulin-binding to IgG. Methodological studies. Horm Metab Res 5: 147-154

4. Colle M, Doyard P, Chaussain JL, Battin J, Job JC (1979) Acanthosis nigricans, hirsutisme et diabetes insulino-resistant. Arch Franc Pediatr 36: 518-523

5. De Meyts P, Roth J (1975) Cooperativity in ligand binding: a new graphic analysis. Biochem Biophis Res Comm 66: 1118-1126

6. Flier JS, Young JB, Landsberg L (1980) Medical Intelligence. Familial insulin resistance with acanthosis nigricans, acral hypertrophy, and muscle cramps. N Eng J Med 303: 970-973

7. Gambhir KK, Archer JA, Carter L (1978) Characteristics of human erythrocyte insulin receptors. Diabetes $27: 701-708$

8. Heding LG (1971) Radioimmunological determination of pancreatic and gut glucagon in plasma. Diabetologia 7: 10-19

9. Heding LG (1972) Determination of total serum insulin in insulintreated diabetics patient. Diabetologia 8: 260-266

10. Heding LG (1975) Radioimmunological determination of human C-peptide in serum. Diabetologia 11: 541-548

11. Heding LG (1977) Specific and direct radioimmunoassay for human proinsulin in serum. Diabetologia 13: 467-474

12. Heding LG, Kasperska-Czyzykowa T (1980) C-peptide and proinsulin after oral glucose. Acta Med Scan Suppl 639: 33-36 
13. Jørgensen KH, Larsen UD (1980) Homogeneous mono- ${ }^{125}$ Iinsulins. Preparation and characterization of mono- ${ }^{125} \mathrm{I}$-(Tyr A 14)- and mono- ${ }^{125} \mathrm{I}$-(Tyr A 19)-insulin. Diabetologia 19:546-554

14. Kahn CR, Flier JS, Bar RS, Archer JA, Gorden P, Martin MM, Roth J (1976) The syndrome of insulin resistance and acanthosis nigricans. N Eng J Med 294: 739-745

15. Kahn CR, Podskalny JM (1980) Demonstration of a primary (genetic) defect in insulin receptors in fibroblasts from a patient with the syndrome of insulin resistance and acanthosis nigricans type A. J Clin Endocrinol Metab 50:1139-1141

16. Mendenhall EN (1950) Tumor of pineal body with high insulin resistance. J Indiana Med Assoc 43: 32-36

17. Pavia C, Albaran IM, Nosas R, Martin MR, Casmitjana R, Potau $N(1980)$ ¿Sindrome " $X$ " en el varon? (acantosis nigricans, resistencia a la insulina, macrogenitosomia) V Congreso Nacional de Diabetes. Sevilla 2-3 Noviembre. Spain. p 61 (Abstract)

18. Perez Corral F, de la Viña $S$, Carbó ME, Barrio R, Yturriaga $R$, Perez Maceda B, Alonso M, Serrano Rios M (1980) Rabson syndrome: Model of insulin resistance due to decreased number and affinity of insulin receptors in erythrocytes. Diabetologia 19: 36 (Abstract)

19. Podskalny JM, Kahn CR (1982) Cell culture studies on patients with extreme insulin resistance. I. Receptor defects on cultured fibroblasts. J Clin Endocrinol Metab 54: 261-268

20. Podskalny JM, Kahn CR (1982) Cell culture studies on patients with extreme insulin resistance. II. Abnormal biological responses in cultured fibroblasts. J Clin Endocrinol Metab 54: 269-275

21. Rechler MM, Podskalny JM (1976) Insulin receptors in cultured human fibroblasts. Diabetes 25: 250-255
22. Serrano Ríos $M$, de la Viña $S$, Barrio $R$, Carbó ME, Yturriaga $R$, Perez Maceda B, Alonso M, Perez Corral F (1981) Two models of insulin resistance studied by insulin binding to erythrocytes. In: Andreani D, De Pirro R, Lauro R, Olefsky J, Roth J (eds) Serono Symposium n ${ }^{\circ} 41$, Current Views on Insulin Receptors. Academic Press, London New York, pp 579-585

23. Taylor SI, Samuels B, Roth J, Kasuga M, Hedo JA, Gorden Ph, Brasel DE, Pokora T, Engel RR (1982) Decreased insulin binding in cultured lymphocytes from two patients with extreme insulin resistance. J Clin Endocrinol Metab 54:919-930

24. Turker WR, Klink D, Goetz F, Zalme E, Knowles HC (1964) Insulin resistance and acanthosis nigricans. Diabetes 13: 395-399

25. West RJ, Lloyd JK, Turne WML (1975) Familial insulin-resistant diabetes, multiple somatic anomalies, and pineal hyperplasia. Arch Dis Child 50: 703-705

Received: 31 March 1982

and in revised form: 28 April 1.983

Professor M. Serrano-Ríos

Servicio de Medicina Interna

Laboratorio 4D

Centro Especial Ramon y Cajal

Carretera de Colmenar Km 9, 100

E-Madrid 34

Spain 